\title{
Article/Artigo
}

\section{High molecular mass fraction in clinical isolates of Paracoccidioides brasiliensis}

\section{Fração de alta massa molecular em isolados clínicos de Paracoccidioides brasiliensis}

\author{
Andréa Longoni Fredrich ${ }^{1}$, Luciene Airy Nagashima ${ }^{1}$, Wander Rogério Pavanelli ${ }^{1}$, Audrey de Souza Marquez ${ }^{2}$, \\ Mari Sumigawa Kaminami ${ }^{1}$, Nilson de Jesus Carlos $^{1}$, Ayako Sano ${ }^{3}$, Mario Augusto Ono ${ }^{1}$ and Eiko Nakagawa Itano ${ }^{1}$
}

\begin{abstract}
Introduction: Different serum levels of the $\mathrm{IgG} / \mathrm{IgE}$ for Paracoccidioides brasiliensis high mass molecular $(\mathrm{hMM})$ fraction $(\sim 366 \mathrm{kDa})$ in the acute and chronic forms of the disease have been reported. Considering the nonexistence of $h M M$ fraction investigation involving clinical isolates of P. brasiliensis, the present study aimed to investigate the presence of the hMM fraction $(\sim 366 \mathrm{kDa})$ in cell free antigens (CFA) from P. brasiliensis clinical isolates. Methods: CFA from 10 clinical isolates and a reference strain (Pb18) were submitted to SDS-polyacrylamide gel electrophoresis (SDS-PAGE) followed by gel image capturing and densitometer analysis. Additionally, CFA from 20 isolates and $\mathrm{Pb} 18$ were analyzed by capture ELISA (cELISA) using polyclonal (polAb) or monoclonal $(\mathrm{mAb}$ ) antibodies to the hMM fraction. Results: The presence of the hMM component was observed in CFA of all samples analyzed by SDS-PAGE/densitometry and by cELISA. In addition, Pearson's correlation test demonstrated stronger coefficients between $\mathrm{hMM}$ fraction levels using $\mathrm{pAb}$ and $\mathrm{mAb}(\mathrm{R}=0.853)$ in cELISA. Conclusions: The soluble hMM fraction was present in all the $P$. brasiliensis clinical isolates analyzed and the reference strain $\mathrm{Pb} 18$, which could be used as a source of this antigen. The work also introduces for first time, the cELISA method for P. brasiliensis hMM fraction detection. Analysis also suggests that detection is viable using polAb or $\mathrm{mAb}$ and this methodology may be useful for future investigation of the soluble hMM fraction $(\sim 366 \mathrm{kDa})$ in sera from PCM patients.
\end{abstract}

Key-words: Paracoccidioidomycosis. Soluble antigen. Capture ELISA. Monoclonal antibodies. IgG.

\section{RESUMO}

Introdução: Diferentes níveis sorológicos de $\mathrm{IgG} / \mathrm{IgE}$ contra a fração de alta massa molecular (hMM) ( 366kDa) de Paracoccidioides brasiliensis têm sido encontrados na PCM aguda e crônica. Considerando a inexistência de investigação sobre esta fração em isolados clínicos de P. brasiliensis, o objetivo deste estudo foi investigar a presença da fração hMM $(\sim 366 \mathrm{kDa})$ no preparado livre de células (CFA) de $P$. brasiliensis obtidos de isolados clínicos. Métodos: CFA de 10 isolados e de cepa de referência (Pb18) foram submetidas à eletroforese em gel de SDS-poliacrilamida (SDS-PAGE) seguida de captura de imagem e análise por densitometria. Adicionalmente, CFA de 20 isolados e de $\mathrm{Pb} 18$ foram analisados por ELISA captura (cELISA) utilizando anticorpos policlonal (polAb) ou monoclonal (mAb) para fração hMM. Resultados: A presença do componente de hMM foi observada em todas as amostras analisadas por SDS-PAGE/densitometria e por cELISA. Adicionalmente, o teste de correlação de Pearson demonstrou forte relação entre os níveis de fração hMM usando pAb e $\mathrm{mAb}(\mathrm{R}=0.853)$ no cELISA. Conclusões: Conclui-se que a fração hMM está presente em todos os isolados clínicos de $P$. brasiliensis analisados e no isolado referencial, sugerindo a possibilidade dos mesmos serem utilizados como fonte desta fração antigênica. Este trabalho também introduz pela primeira vez o método de cELISA para detecção da fração hMM de $P$. brasiliensis, sugerindo que detecção utilizando anticorpos polAb ou $\mathrm{mAb}$ é viável e essa metodologia poderá ser útil para investigação futura desta fração solúvel $(\sim 366 \mathrm{kDa})$ em soros de pacientes com PCM.

Palavras-chaves: Paracoccidioidomicose. Antígeno solúvel. ELISA de captura. Anticorpos monoclonais. IgG.

1. Department of Pathology Science, Biological Science Center, State University of Londrina, Londrina, PR, Brazil. 2. Health Science Research Center, University North of Paraná, Londrina, PR, Brazil. 3. Medical Mycology Research Center, Chiba University, Chiba, Japan.

Address to: Dra. Eiko Nakagawa Itano. Deptํㅡㄹ Ciências Patológicas/CCB/UEL. Campus Universitário, 86051-970 Londrina, PR, Brasil.

Phone: 5543 3371-4469; Fax: $55433371-4207$

e-mail: itano@uel.br

Received in 21/01/2010

Accepted in 27/07/2010

\section{INTRODUCTION}

Paracoccidioidomycosis (PCM), a deep mycosis endemic in Latin America, is caused by the thermally dimorphic fungus Paracoccidioides brasiliensis, which develops as yeast at body temperature and as mycelium at room temperature. P. brasiliensis causes natural infections by inhalation of conidia or mycelial elements ${ }^{1}$. Most exposed subjects develop an asymptomatic infection, although some individuals present clinical manifestations that can vary from benign and localized to severe and disseminated forms ${ }^{2}$. Two forms of the disease are distinguished: the acute or subacute and chronic form. The acute form is more severe and rare, while the chronic form occurs more frequently and mostly affects adult males ${ }^{3,4}$.

Usually, PCM diagnosis is inferred from indirect evidence obtained via serological tests and clinically relevant antigens have been identified and adapted for use in immunoassays for the detection of specific antibodies 5 . For this purpose, several fungal components have already been identified. The antigens most frequently identified in PCM patient sera are the glycoproteins of $43 \mathrm{kDa}(97-100 \%)^{6-8}$, the main PCM diagnostic antigen ${ }^{6,7,9,10}, 160 \mathrm{kDa}(78 \%)$ and $70 \mathrm{kDa}(60 \%)^{8}$.

The other alternative laboratory approach for diagnosis of PCM is the detection of circulating $P$. brasiliensis antigens. The inhibition ELISA methodology (inh-ELISA) is able to detect gp43 in $96.3 \%$ of PCM patients, mainly in those with the acute form of the disease $(100 \%)^{11}$. Gp70 has also been detected in the urine or in cerebrospinal fluid (CSF) of PCM patients ${ }^{12,13}$. Gómez et al ${ }^{14,15}$ reported the use of inh-ELISA and detected gp 87 circulating antigen in sera from patients with active disease.

Puccia et $\mathrm{al}^{9}$ demonstrated polydispersed highmolecular mass glycoprotein, with heterogeneous electrophoresis migration. From this heterogeneous electrophoresis migration Marquez et $\mathrm{al}^{16}$ isolated fractions ranging from $278 \mathrm{kDa}$ to $466 \mathrm{kDa}$ (mean approximately $366 \mathrm{kDa}$ ) obtained from sonicated 
or cell free antigens (CFA) preparations. Moreover, different serum levels of the $\mathrm{IgG} / \mathrm{IgE}$ to the hMM fraction was verified in sera of acute and chronic PCM patients and the authors suggested the analysis as a new characteristic to differentiate between these two clinical forms of the disease ${ }^{16}$.

Taking into account the lack of data regarding the soluble hMM fraction $(\sim 366 \mathrm{kDa})$ in $P$. brasiliensis clinical isolates and the immunological methodology for identifying it, in the present study, the hMMAg antigen was investigated in different clinical isolates and capture ELISA (cELISA) was introduced. In principle, observation verified that all the $P$. brasiliensis samples analyzed produced the hMM fraction $(\sim 366 \mathrm{kDa})$. In addition, this hMM fraction was detected by cELISA using monoclonal or polyclonal antibodies to the hMM fraction.

\section{METHODS}

\section{Fungal isolates}

Clinical isolates of $P$. brasiliensis of the chronic form of PCM disease were obtained: 17 isolates (LDR1 to LDR17) from Londrina State University (MOOI/CCS, HC, HC, Londrina State University, Londrina, Paraná) patients (2000 to 2006); two isolates (RC-Wang and RC-Hori) from Chiba University, Chiba, Japan; one isolate (EPM-01) and reference strain (Pb18) from UNIFESP, São Paulo, Brazil. P. brasiliensis strains were maintained on potato dextrose agar (Difco Laboratories, MI, USA) slants at room temperature. Prior to experiments, samples of the isolates were inoculated onto a slant of brain heart infusion agar (BHI, Difco Laboratories) supplemented with $1 \%$ dextrose and cultured at $35^{\circ} \mathrm{C}$ to produce the yeast form and maintained by subculturing at $35^{\circ} \mathrm{C}$ at 5-day intervals on Sabouraud agar (Micromed, Rio de Janeiro, RJ, Brazil).

\section{Cell free antigens preparation}

Yeast cells were collected and the CFA samples were obtained according to Camargo et $\mathrm{al}^{17}$, modified by the addition of PMSF protease inhibitor at $2.5 \mathrm{mM}$ to the supernatant. The protein concentration was determined by the Lowry method ${ }^{18}$, adjusted to $3 \mathrm{mg} / \mathrm{mL}$ and stored in $-80^{\circ} \mathrm{C}$ freezer until ready to use.

\section{Cell free antigens analysis by SDS-PAGE}

Cell free antigens $(3 \mathrm{mg} / \mathrm{mL})$ samples, obtained as described above, were mixed with the reducing sample buffer $(62.5 \mathrm{mM}$ Tris$\mathrm{HCl}, \mathrm{pH} 6.8,2 \%$ sodium dodecyl sulfate (SDS), 10\% glycerol, $10 \%$ $\beta$-mercaptoethanol and $0.05 \%$ bromophenol blue) and boiled for $3 \mathrm{~min}$. The antigens were separated by SDS-polyacrylamide gel electrophoresis (7.5\%), in tris-glycine buffer, $\mathrm{pH} 8.2$, at 125v. Protein standards with the following molecular masses were used: myosin $(201.1 \mathrm{kDa}) ; \beta$-galactosidase $(115.7 \mathrm{kDa})$; bovine serum albumin $(93.6 \mathrm{kDa})$; ovalbumin $(50.3 \mathrm{kDa})$; carbonic anhydrase $(37.3 \mathrm{kDa})$. Using specific densitometer software, Glob-Al Scan (Cellogel Electrophoresis Co, Milan, Italy), silver stained dehydrated SDSelectrophoresis gel image was captured, the specific cutoff point of that defines the area of the hMM fraction band $(\sim 366 \mathrm{kDa})$ was indicated and the result automatically calculated and expressed in percentages.

\section{Capture ELISA for IgG-hMM fraction}

ELISA immunoplates sensitized with rabbit IgG anti-hMM fraction $(25 \mu \mathrm{g} / \mathrm{ml})$ were incubated with CFA samples at $30 \mu \mathrm{g} / \mathrm{ml}$ at $37^{\circ} \mathrm{C}$ for $1 \mathrm{~h}$ and then with polyclonal mouse $\operatorname{IgG}$ anti-hMM
$(\mathrm{IgG} \mathrm{pAb})(30 \mu \mathrm{g} / \mathrm{ml})$, anti-mouse IgG peroxidase conjugate and OPD (100 $\mu \mathrm{L}$ well). The absorbance was read at $492 \mathrm{~nm}$. Additionally, cELISA for hMM fraction level determination was performed as described, substituting polyclonal mouse IgG anti-hMM fraction for monoclonal IgG anti-hMM fraction (IgG mAb) as secondary antibodies. Polyclonal rabbit and mouse antibodies were produced by using the $h M M$ fractions obtained, according to Pavanelli et al ${ }^{19}$ for immunizations. A monoclonal antibody was obtained by spleen cells (from immunized BALB/c mice with the hMM fraction) fused with P3U1 cell line by using PEG. Hybridomas were screened by ELISA with hMM fraction $(\sim 366 \mathrm{kDa})$ and cloned by limiting dilutions. Pristane-primed BALB/c mice were injected i.p. with hybridoma and IgG purified (Sepharose-G protein column) from ascite fluid. The cutoff was determined as the mean plus 2 standard deviations of the absorbance obtained with control: primary rabbit IgG anti-hMM, secondary mouse $\mathrm{pAb}$ or $\mathrm{mAb}$ IgG and peroxidase conjugate without the CFA sample.

\section{Statistical analysis}

Statistical comparisons were performed by analysis of variance (ANOVA) and by the Tukey test. All values are reported as the mean \pm SD of the mean, with significance assumed in the range of $p<0.05$. Pearson's correlation was applied between $\mathrm{hMM}$ fraction levels using IgG $\mathrm{pAb}$ and $\mathrm{mAb}$ anti-hMM fraction and a significant correlation was considered when $r \geq 0.50$.

\section{Ethical}

This study was approved by the Internal Scientific Commission and the Bioethics in Research Committee of the State University of Londrina (Londrina, PR, Brazil).

\section{RESULTS}

\section{CFA analysis by SDS-PAGE}

The presence of the hMM fraction was observed in CFA from all the clinical isolates and reference Pb18 by SDS-PAGE. The SDSPAGE was submitted to densitometry in an attempt to quantify the hMM fraction. The results show that $20.5 \pm 5.7 \%$ (clinical isolates) and $16.7 \%(\mathrm{~Pb} 18)$ from CFA correspond to the hMM fraction (Figure 1). This study indicates that this antigen is present in different clinical isolates from chronic patients and could be used as source of the hMM fraction.

\section{Capture ELISA for hMM fraction levels in CFA samples}

Various researchers have attempted to detect circulating antigens in PCM patients using polyvalent antigens or antibodies in differentassays. For this purpose, the presence of the hMM fraction in CFA samples was determined using cELISA expressed as optical density units (OD). Analysis of the result verified the presence of the hMM fraction in $\mathrm{Pb} 18$, a strain characterised as highly virulent, and in all the clinical isolates of $P$. brasiliensis, with the use of polAb or $\mathrm{mAb}$ to the hMM fraction (Table 1). All values greater than the values obtained in the control systems of polyclonal/polyclonal or monoclonal/monoclonal with free samples of CFA plus $2 \mathrm{x}$ standard $(0.118 \pm 0.008$ and $0.086 \pm 0.005$, respectively) were considered as positive.

\section{Correlation analysis}

Analysis of the results confirmed a strong correlation between $\mathrm{hMM}$ fraction levels with IgG pAb or mAb anti-hMM as the secondary antibody $(\mathrm{r}=0.853)$ (Figure 2$)$. This result demonstrates that the hMM fraction can be detected by cELISA using monoclonal or polyclonal antibodies to hMM, as a secondary antibody. 


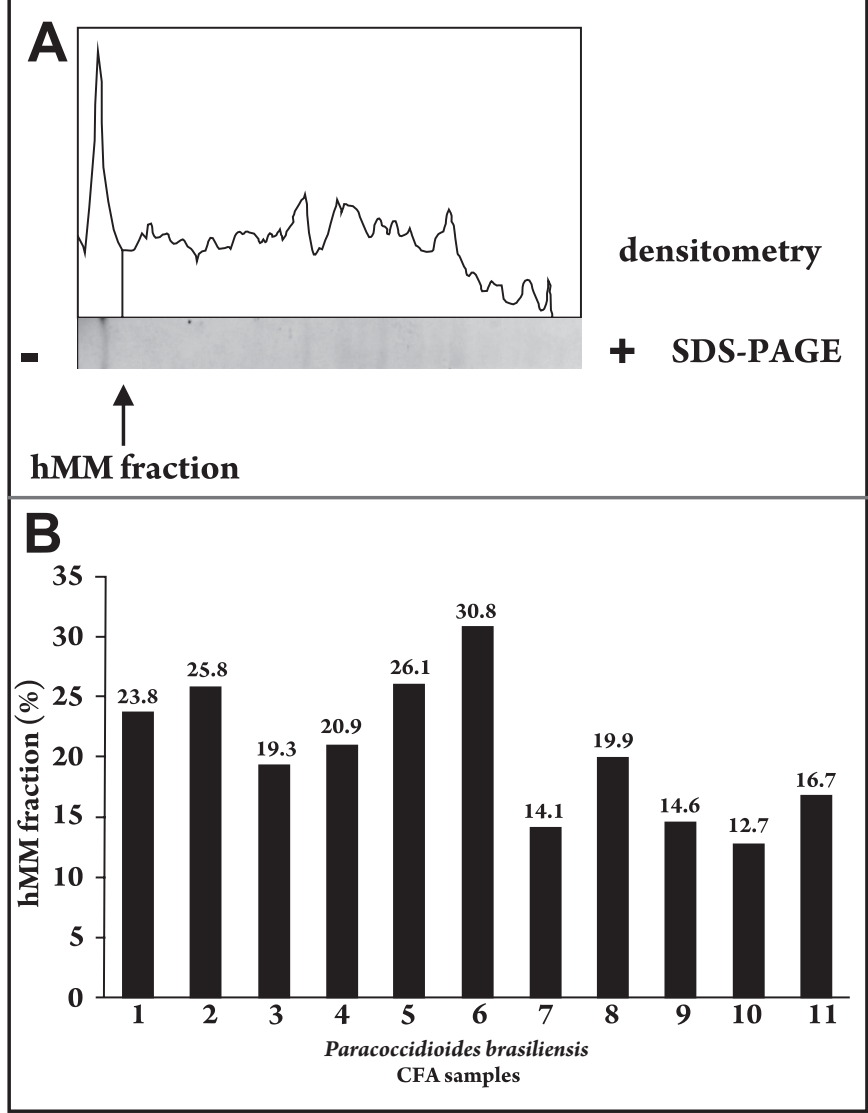

FIGURE 1 - The hMM fraction in CFA from $P$. brasiliensis by SDS-PAGE and densitometry. A) P. brasiliensis CFA sample was separated using 7.5\% SDSpolyacrylamide gel electrophoresis (SDS-PAGE), silver stained and dehydrated. The gel image was captured and the specific cutoff point of hMM fraction $(\sim 366 \mathrm{kDa})$ was marked and equivalent area was automatically calculated and expressed in percentages of $\mathrm{hMM}$ fraction. B) Percentage of hMM fraction in relation to all other fractions in CFA from clinical isolates of $P$. brasiliensis: (1) LDR13, (2) LDR11, (3) EPM-01, (4) LDR16, (5) LDR17, (6) RC-Hori, (7) RCWang, (8) LDR12, (9) LDR14, (10) LDR10 and reference strain (11) Pb18.

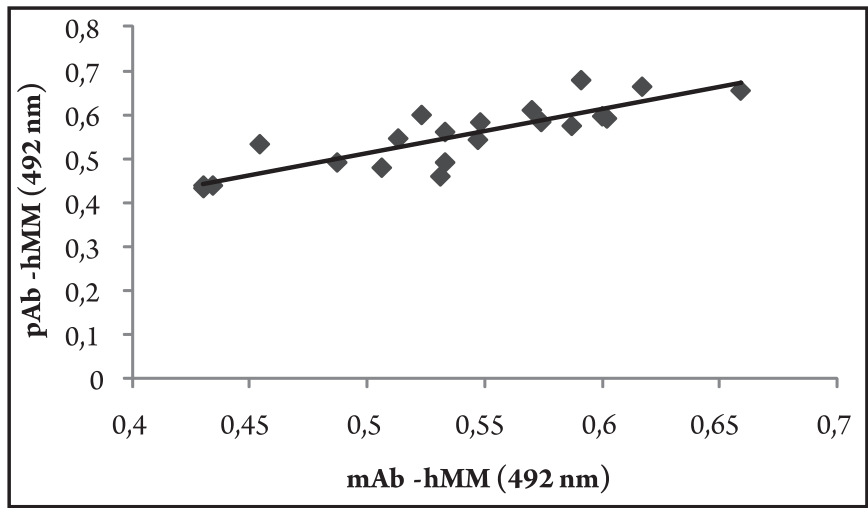

FIGURE 2 - Pearson's correlation tests between hMM fraction levels by capture ELISA (cELISA) using monoclonal (mAb) or polyclonal (polAb). The cELISA results showed a stronger correlation between hMM fraction levels with IgG pAb or $\mathrm{mAb}$ anti-hMM as a secondary antibody $(r=0.85)$.

\section{DISCUSSION}

In this work, the hMM fraction was detected in all the $P$. brasiliensis clinical isolates and the reference strain $\mathrm{Pb} 18$ by SDSPAGE, suggesting that all these $P$. brasiliensis could be used as a source of this fraction.
TABLE 1 - High molecular mass fraction $(\sim 366 \mathrm{KDa})$ levels in CFA from clinical isolates Paracoccidioides brasiliensis $(\mathrm{Pb})$ by capture ELISA, expressed in optical density units.

\begin{tabular}{cccc} 
Reference strain & Pb & pAb-hMM & mAb-hMM \\
\hline Pb18 & 0.600 & 0.596 \\
LDR1 & 0.659 & 0.655 \\
LDR2 & 0.617 & 0.664 \\
LDR3 & 0.587 & 0.574 \\
LDR4 & 0.531 & 0.458 \\
LDR5 & 0.434 & 0.437 \\
LDR6 & 0.574 & 0.583 \\
LDR7 & 0.548 & 0.582 \\
LDR8 & 0.591 & 0.679 \\
LDR9 & 0.570 & 0.610 \\
RC-WANG & 0.547 & 0.542 \\
LDR10 & 0.513 & 0.545 \\
EPM-01 & 0.533 & 0.490 \\
LDR11 & 0.454 & 0.532 \\
RC-HORI & 0.430 & 0.431 \\
LDR12 & 0.506 & 0.478 \\
LDR13 & 0.533 & 0.560 \\
LDR14 & 0.487 & 0.490 \\
LDR15 & 0.430 & 0.437 \\
LDR16 & 0.523 & 0.599 \\
LDR17 & 0.602 & 0.591 \\
& & $\mathbf{0 . 5 3 7} \pm \mathbf{0 . 0 6 4}$ & $\mathbf{0 . 5 4 9} \pm \mathbf{0 . 0 7 6}$
\end{tabular}

ELISA immunoplates sensitized with rabbit IgG anti-hMM were incubated with CFA samples and then with polyclonal mouse $\operatorname{IgG}$ anti-hMM (pAb-hMM) or with monoclonal mouse IgG anti-hMM (mAb-hMM). After incubation with anti-mouse IgG peroxidase conjugate, absorbance was read at $492 \mathrm{~nm}$. All values higher than the controls: polyclonal/polyclonal $(0.118 \pm 0.008)$ or $\mathrm{polyclonal} /$ monoclonal $(0.086 \pm 0.005)$, with free CFA sample, plus $2 \mathrm{x}$ standard were considered positive.

For diagnostic purposes, the presence of the target antigen in all isolates of the P. brasiliensis is important. The present study indicates that this antigen is present in different clinical isolates from chronic patients as the common P. brasiliensis antigen. However, further studies involving larger sample of isolates are required to confirm these findings.

Panunto-Castelo et $\mathrm{al}^{8}$ identified hMM antigens with 172 or $160 \mathrm{kDa}$ in exoAg from three P. brasiliensis isolates (DGO, C-9 and BAT). In this study, the considered hMM band identified in CFA from the P. brasiliensis isolates presented $\sim 366 \mathrm{kDa}$ and is, therefore, a different $\mathrm{hMM}$ antigen.

The detection of circulating antigens is a useful approach for serodiagnosis for monitoring PCM treatment. The gp43 glycoprotein, one of the most important immunodominant antigens of $P$. brasiliensis, has been extensively investigated, particularly in relation to diagnosis ${ }^{20-22}$. Gp43 has been detected at higher levels in PCM patient sera as circulating antigen $\mathrm{s}^{22}$ and in CSF and bronchoalveolar lavage (BAL) fluid samples from PCM patients ${ }^{11}$. However, recently the existence of a P. brasiliensis isolate presenting differences in this major antigen coding gene gp $43^{23,24}$ has been demonstrated and speculation of the possibility of a new species in the genus Paracoccidioides has been noted. Considering genetic differences in gp 43 according to P. brasiliensis isolate, it has become important to investigate other $P$. brasiliensis antigens for diagnosis.

Besides gp $43^{11}$, the $87-\mathrm{kDa}$ molecule ${ }^{15}$, gp $70^{13}$ and the high molecular mass antigen with $160 \mathrm{kDa}^{25}$ were also introduced as potential candidates for diagnosis and/or for follow-up of patients with PCM. 
Panuto-Castelo et $\mathrm{al}^{8}$ demonstrated that the hMM antigens $(172$ or $160 \mathrm{kDa})$ are highly reactive with serum IgG of patients with acute or chronic PCM, indicating their potential application in the diagnosis and follow-up of the disease. In addition, Coltri et $\mathrm{al}^{25}$ characterized this antigen as a protein of $160 \mathrm{kDa}$, designated paracoccin, with selective binding to immobilized GlcNAc and able to interact with laminin.

In this study, the association between SDS-PAGE and densitometry analysis shows that approximately $16-20 \%$ of $P$. brasiliensis CFA antigens correspond to the hMM fraction. Considering the proportion and as a soluble antigen present in CFA, we speculate that its presence may also be observed as a soluble antigen during infection, similar to other antigens, such as gp43 or gp70, present in CFA and in the serum ${ }^{11,13,22,26}$, with the potential for diagnosis and follow-up of the PCM patients. Thus, the hMM fraction is also important when considering the distinct isotypic humoral immune response to $\mathrm{hMM}$ antigens with $\sim 336 \mathrm{kD}$ a observed in the acute and chronic forms of the PCM disease, which suggest that it has potential as a new biomarker for differentiating these two clinical forms ${ }^{16}$.

In this study cELISA was introduced to detect the hMM fraction in clinical isolates and the reference $\mathrm{Pb} 18$ strain was introduced and the presence of the hMM fraction was detected in all the samples analyzed, in agreement with SDS-PAGE. This study is qualitative and the results are expressed as optical density. cELISA has the advantage of being able to process large numbers of samples at the same time and presents high sensitivity and a high specificity. The analysis was performed using polAb or $\mathrm{mAb}$ to the $\mathrm{hMM}$ fraction as a secondary antibody and the results showed a stronger correlation between $\mathrm{hMM}$ fraction levels obtained using $\mathrm{pAb}$ or $\mathrm{mAb}$ anti-hMM. cELISA with specific polAb and $\mathrm{mAb}$ was used in previous studies by our group to determine circulating soluble gp43 levels in $\mathrm{PCM}^{22}$ and determining plasmatic hMM fraction levels in PCM patients by cELISA will be the object of future investigations.

Unexpectedly, the results ofELISA showed homogeneity. We believe that regardless of differences in isolates or strains, these components are better preserved and produced more homogeneously, as observed with other antigens reported in the literature ${ }^{8}$. The same isolates showed less homogeneity in relation to gp43 determined by capture ELISA (data not shown) and the heterogeneity observed in the percentage of the $\mathrm{hMM}$ fraction in the electrophoresis was due to variations in the other components present in CFA (data not shown).

In conclusion, the soluble hMM fraction was present in all the $P$. brasiliensis clinical isolates analyzed and the reference strain $\mathrm{Pb} 18$, which could be used as source of this fraction. The work also introduced for first time the capture ELISA method for P. brasiliensis hMM fraction $(\sim 366 \mathrm{kDa})$ detection.

\section{CONFLICT OF INTEREST}

The authors declare that there is no conflict of interest.

\section{FINANCIAL SUPPORT}

This work was supported financial by the Financiadora de Estudos e Projetos (FINEP), the Secretaria de Estado da Ciência, Tecnologia e Ensino Superior (SETI/PR), the Fundação Araucaria/PR, Próreitoria de Extensão (PROEX/UEL), the Pró-reitoria de Pesquisa (PROPPG/UEL) and the Coordenação de Aperfeiçoamento de Pessoal de Nível Superior (CAPES).

\section{REFERENCES}

1. Restrepo A, Tobón AM. Paracoccidioides brasiliensis. In: Mandell GL, Bennett JE, Dollin R, editors. Principles and Practice of Infectious Diseases. $6^{\text {th }} \mathrm{ed}$. Philadelphia: Elsevier; 2005. p. 3062-3068.

2. Borges-Walmsley MI, Chen D, Shu X, Walmsley AR. The pathobiology of Paracoccidioides brasiliensis. Trends Microbiol 2002;10:80-87.

3. Shikanai-Yasuda MA, Telles Filho FQ, Mendes RP, Colombo AL, Moretti ML, Grupo de Consultores do Consenso em Paracoccidioidomicose. Consenso em Paracoccidioidomicose. Rev Bras Med Tropical 2006; 39:297-310.

4. Franco M, Montenegro MR, Mendes RP, Marques SA, Dillon NL, Mota NGS Paracoccidioiodomycosis: a recently proposed classification of its clinical forms. Rev Soc Brasil Med Trop 1987; 20:129-132.

5. Ferreira-da-Cruz MF, Galvão-Castro B, Daniel-Ribeiro CT. Isolation and antigenicity of a 45-kilodalton Paracoccidioides brasiliensis immunodominant antigen. Infect Immun 1992; 60:2667-2671.

6. De-Camargo Z, Unterkircher C, Campoy SP, Travassos LR. Production of Paracoccidioides brasiliensis exoantigens for immunodiffusion tests. J Clin Microbiol 1988; 26:2147-2151.

7. Taborda CP, Camargo ZP. Diagnosis of paracoccidioidomycosis by passive haemagglutination assay of antibody using a purified and specific antigen-gp43. J Med Vet Mycol 1993; 31:155-160.

8. Panunto-Castelo A, Freitas-da-Silva G, Bragheto IC, Martinez R, RoqueBarreira MC. Paracoccidioides brasiliensis exoantigens: recognition by IgG from patients with different clinical forms of paracoccidioidomycosis. Microbes Infect 2003; 5:1205-1211.

9. Puccia R, Schenkman S, Gorin PA, Travassos LR. Exocellular components of Paracoccidioides brasiliensis: identification of a specific antigen. Infect Immun 1986; 53:199-206.

10. Puccia R, Travassos LR. 43-kilodalton glycoprotein from Paracoccidioides brasiliensis: immunochemical reactions with sera from patients with paracoccidioidomycosis, histoplasmosis, or Jorge Lobo's disease. J Clin Microbiol $1991 ; 29: 1610-1615$.

11. Marques-da-Silva SH, Colombo AL, Blotta MHSL, Lopes LD, Queiroz-Telles F, Camargo ZP. Detection of circulating gp43 antigen in serum, cerebrospinal fluid and bronchoalveolar lavage of patients with paracoccidioidomycosis. J Clin Microbiol 2003; 41:3675-3680.

12. Salina MA, Shikanai-Yasuda MA, Mendes RP, Barravieira B, Mendes-Giannini MJS. Detection of circulating Paracoccidioides brasiliensis antigen in urine of paracoccidioidomycosis patients before and during treatment. J Clin Microbiol 1998; 36:1723-1728.

13. Marques-da-Silva SH, Mattos Grosso D, Lopes JD, Colombo AL, Blotta MHSL, Queiroz-Telles F, et al. Detection of Paracoccidioides brasiliensis gp 70 circulating antigen and follow-up of patients undergoing antimycotic therapy. J Clin Microbiol 2004; 42:4480-4486.

14. Gómez BL, Figueroa JL, Hamilton AJ, Ortiz B, Robledo MA, Hay RJ, et al. Use of monoclonal antibodies in diagnosis of paracoccidioidomycosis: new strategies for detection of circulating antigens. J Clin Microbiol 1997; 35:3278-3283.

15. Gómez BL, Figueroa JI, Hamilton AJ, Diez S, Rojas M, Tobón AM, et al. Restrepo A. Antigenemia in patients with paracoccidioidomycosis: detection of the 87 kilodalton determinant during and after antifungal therapy. J Clin Microbiol 1998; 36:3309-3316.

16. Márquez AS, Vicentini P, Ono MA, Watanabe MAE, Camargo ZP Itano EN. Reactivity of antibodies from patients with acute and chronic paracoccidioidomycosis to a high-mass molecular antigen from Paracoccidioides brasiliensis. J Clin Labor Anal 2005; 19:199-204.

17. Camargo ZP, Taborda CP, Rodrigues EG, Travassos LR. The use of cell-free antigens of Paracoccidioides brasiliensis in serological tests. J Med Vet Mycol $1991 ; 29: 31-38$.

18. Lowry OH, Rosebrough NJ, Farr AL, Randall RJ. Colorimetric assays: Lowry's method for protein determination. J Biol Chem 1951; 193:265-275.

19. Pavanelli WR, Kaminami MS, Gerez JR, Sano A, Ono MA, Camargo ICC, et al Protection induced in BALB/c mice by the high-molecular-mass (hMM) fraction of Paracoccidioides brasiliensis. Mycopathologia 2007; 163:117-128. 
20. Camargo ZP, Unterkircher C, Travassos L. Identification of antigenic polypeptides of Paracoccidioides brasiliensis by immunoblotting. J Med Vet Mycol 1989; 27:407-412.

21. Brummer E, Castañeda E, Restrepo A. Paracoccidioidomycosis: an update. Clin Microbiol Rev 1993; 6:89-117.

22. Miura CSN, Estevão D, Lopes JD, Itano EN. Levels of specific antigen (gp43), specific antibodies, and antigen-antibody complexes in saliva and serum of paracoccidioidomycosis patients. Med Mycol 2001; 37:423-428.

23. Carrerro L, Nino-Vega G, Teixeira MM, Carvalho MJA, Soares CM, Pereira M, et al. New Paracoccidioides brasiliensis isolate reveals unexpected genomic variability in this human pathogen. Fungal Genet Biol 2008; 45:605-612.

24. Takayama A, Itano EN, Sano A, Ono MA, Kamei K. An atypical Paracoccidioides brasiliensis clinical isolate. Med Mycol 2009; 47:01-09.

25. Coltri KC, Casabona-Fortunato AS, Gennari-Cardoso ML, Pinzan CF, Ruas LP, Mariano VS, et al. Paracoccin, a GlcNAc-binding lectin from Paracoccidioides brasiliensis, binds to laminin and induces TNF-alpha production by macrophages. Microbes Infect 2006; 8:704-713.

26. Stambuk BU, Puccia R, De-Almeida ML, Travassos LR, Schenkman S. Secretion of the 43kDa glycoprotein antigen by Paracoccidioides brasiliensis. J Med Vet Mycol $1988 ; 26: 367-373$. 